\title{
Motivation and involvement in adventure tourism activities: A Chinese tourists' perspective
}

\author{
Dr. Xin Jin* \\ Department of Tourism, Sport and Hotel Management \\ Griffith University \\ Parklands Drive, Southport, 4222, QLD \\ Australia \\ Tel: +61 755527413 Fax: +61 55528507 \\ Email: x.jin@griffith.edu.au \\ Ms. Yang Xiang \\ Department of Tourism, Sport and Hotel Management \\ Griffith University \\ Dr. Karin Weber \\ School of Hotel \& Tourism Management \\ The Hong Kong Polytechnic University \\ 17 Science Museum Rd \\ Hung Hom, Kowloon \\ Hong Kong, SAR, China \\ Ms. Yang Liu \\ School of Engineering and Built Environment \\ Griffith University
}

Keywords: Adventure tourism, Chinese Tourists, motivation, involvement, personality

Submitted to the Asia Pacific Journal of Tourism Research

* Corresponding author

This paper has not been published elsewhere and has not been submitted simultaneously for publication elsewhere. 


\begin{abstract}
:
This research aims to explore Chinese tourists' motivations and involvement in adventure tourism activities, as well as if and how personality and location affect their motivation and involvement. Using a survey that collected 252 responses, this research suggests that stimulusavoidance and intelligence seeking are the two most important motivational forces. Results indicate that respondents would prefer overseas locations for these activities due to perceptions of greater safety and security, better service, and higher-quality facilities. Respondents who rated themselves as 'open' or 'closed' in personality differ regarding motivations and involvement. Practical implications are discussed, and recommendations for future research are provided.
\end{abstract}




\section{Introduction}

China continued to be world's top international tourism spender in 2018, with US \$257.7 billion expenditure on international tourism (UNWTO, 2018). China's domestic tourist trips in 2008 amounted to 5.54 billion in 2018 (Fes, 2019). The growing national economy, the abundant tourism resources, and the improved living standards have all contributed to the boost of China's domestic and international tourism (Wen, 1997, Jin \& Wang, 2016).

Whether travelling domestically or overseas, Chinese tourists have traditionally held a preference for trips consisting of sightseeing, shopping, culture and heritage, entertainment, participatory activities and dining/eating (Chow \& Murphy, 2008). Contemporary studies have discussed tourism activities that involve Chinese tourists' travelling for special interests, such as wine (Qiu, Yuan, Ye, \& Hung, 2013), food (Chang, Kivela, \& Mak, 2010), spa experiences on holiday (Lo, Qu, \& Wetprasit, 2013), medical tourism in Hong Kong (Ye, Qiu, \& Yuen, 2011), shopping (Choi, Liu, Pang, \& Chow, 2008; C. B. Wong, Wong, Ng, \& Wong, 2013), water rafting (Buckley, McDonald, Duan, Sun, \& Chen, 2014), and gambling (Wan, 2013; Wong, 2012; Wong \& Rosenbaum, 2011).

Chinese tourists' experience in conducting adventure activities while travelling overseas have been investigated but with limited discussions (Chow \& Murphy, 2008; Ryan \& Mo, 2002). Presently, an increasing number of Chinese tourists are no longer content with sightseeing or shopping, but desire an experience encompassing excitement and adventure (Chow \& Murphy, 2008). Tourism marketers and operators should advance their understanding of the demand and desire of Chinese tourists to better cater to the market.

Weber (2001) called for more research to explore more individual perceptions of adventure activities, in addition to expanding the research scope to cover more market segments. This research aims to examine Chinese tourists' motivation and involvement in adventure tourism activities and assess if and how personality and location influence their motivation and involvement for adventure activities. It does so by drawing on established leisure motivation and consumer involvement scales, in addition to investigating the influence of personality on respondents' motivation towards adventure tourism. In particular, the following questions are addressed:

1. What adventure activities are Chinese tourists interested in?

2. Where would Chinese tourists like to conduct their adventure tourism activities, domestically or overseas?

3. What factors affect their choice of destination for adventure activities?

4. What are the underlying dimensions of Chinese tourists' involvement in and motivation for adventure activities?

5. Will personality influence Chinese tourists' motivation for and involvement in adventure activities? 


\section{Literature Review}

\section{Special Interest and Adventure Tourism}

Poon (1993) suggested that tourism focusing on special interests is growing at a more rapid rate than traditional mass tourism due to the emergence of new consumers, technologies, production practices, management techniques and frame conditions. Adventure tourism is distinct from and overlaps with other tourism sectors like activity tourism, nature-based tourism, discovery/cultural tourism and expedition tourism (Swarbrooke, Beard, Leckie, \& Pomfret, 2003). Swarbrooke et al. (2003) posited that adventure tourism is a combination of adventure and tourism, where adventure is characterized by some core qualities including uncertain outcomes, danger and risk, challenge, anticipated rewards, novelty, stimulation and excitement, escapism and separation, exploration and discovery, absorption and focus, and contrasting emotions. Relying on natural features and generally requiring specialized equipment, adventure tourism is also increasingly offered as guided commercial tours, in which service providers take a genuine responsibility for providing safe, pleasurable, sensational and satisfying experiences to a wide range of customers (Buckley, 2007; 2012). One of the key forces driving adventure tourism is the changing values that generate environmental consciousness and a sense of being close to nature, which are vital concepts in ecotourism as well as adventure tourism (Buckley, 2006).

From the participants perspective, the core part of adventure tourism is to seek insight and knowledge (Walle, 1997) and insight does not only involve competence and mastery, but also discovery and exploration (Gyimóthy \& Mykletun, 2004). The experience could be a lively exploration in pursuit of thrill, pleasure and fun (Cater, 2006). Also, participants perceive risks differently from the operators and the responsibility for risk management lies increasingly with the operators (Cater, 2006). Multi-activity travel package in exotic destinations and operator expertise are services preferred by participants (Sung, Morrison \& O'leary, 2000). Service operators should provide better information and access to assist with inexperienced participants (Jamal, Aminudin \& Kausar, 2019).

Only several studies have examined the adventure tourism of Chinese tourists. The operational model of China's domestic river-based adventure tourism is different from that in the West regarding waterway, watercraft, facilities, safety, access, price, enterprise structure and marketing (Buckley et al., 2014). The young Chinese adventure tourists do not seem to have sufficient knowledge of Western-style water rafting products and are easily satisfied with slightly improved safety equipment, pre-trip briefing and environmental management (Buckley et al., 2014). There are barriers for Chinese group tourists to attempt adventure activities while travelling overseas. The perceived operational, financial and physical risks, as well as lack of perceived importance and value are major barriers preventing Chinese outbound package tourists from conducting special interest and adventure tourism activities (Jin \& Sparks, 2017). Given the sporadic research on Chinese tourists' participation in adventure tourism, it is timely and important to explore the motivations, involvement and other factors that impact the participation in adventure tourism activities by the Chinese market.

\section{Motivation in leisure and tourism}

In order to understand human motivation, it is necessary to study the concept of need which is central to most content theories of motivation (Witt \& Wright, 1992). Maslow's need hierarchy (1943) depicts the different levels of needs that people have and how these needs can be fulfilled. 
Similarly, Iso-Ahola (1980) proposed the idea of intrinsic motivation. He argued that people are intrinsically motivated to take part in a leisure activity to obtain intrinsic rewards such as feelings of competence and self-determination. This intrinsic motivation is identical to Maslow's selfactualization as people desire to do what they want and what they are capable of doing. The application of Maslow's hierarchy of needs in the context of tourist motivation resulted in a number of scales measuring intrinsic motivations.

Beard and Ragheb (1983) developed a 48-item instrument to measure leisure motivation. Four subscales (intellectual, social, competence-mastery, and stimulus-avoidance) have been identified, relating to psychological and sociological reasons that lead people to participate in leisure activities. People engage in leisure activities for intellectual reasons involving mental activities such as learning, exploring, and creating. They would also like to satisfy two basic needs by engaging in leisure activities - the need for friendship and interpersonal relationships, and the need for the esteem of others. This component relates to social reasons. In addition, people would like to achieve, master, challenge, and compete in leisure activities they engage in. Lastly, escape and getting away from the everyday environment account for people participating in leisure activities.

Beard and Ragheb (1983) model has been tested in leisure and tourism studies using a wide variety of samples. For example, Murray and Nakajima (1999) tested the scale with a sample of Japanese respondents and yield four underlying factors: Intellectual, Competence/Mastery, Stimulus Avoidance, Peer Influence and Friendship. It has been utilised in nature and adventurebased tourism studies (e.g., Prebensen, Woo, Chen, and Uysal, 2013 on Norway nature-based tourism). The scale proves to be robust in different cultural settings, although partial modification of the original scale maybe needed. This study tests the validity of this model using a Chinese sample in the context of adventure tourism.

\section{Involvement}

Involvement gained primary attention in social psychology in the 1940s (Filo, Chen, King, \& Funk, 2013; Hu \& Yu, 2007) and then has been widely studied in the marketing and consumer behavior domains (e.g., Chou \& Huang, 2010; Havitz \& Howard, 1995; Traylor, 1981). It plays an important role in shaping consumer behavior in response to advertising (e.g., Krugman, 1965; 1966) and decision-making (e.g., Kapferer \& Laurent, 1985; Mittal, 1989; Zaichkowsky, 1985). The definition of involvement varies according to different authors (Freedman, 1964; Mittal, 1989) but is generally related to the amount of arousal, interest, or drive evoked by a particular stimulus or situation (Mittal, 1989) and is in relation to an object based on inherent needs, values, and interests (Zaichkowsky, 1985).

Kapferer and Laurent (1985) established a multi-dimensional scale - Consumer Involvement Profiles (CIP) - to measure consumer involvement from five facets of involvement: (1) the perceived importance/interest in the product; (2) the perceived pleasure or hedonic value of the product; (3) the perceived importance of the negative consequences in case of a poor choice; (4) the perceived probability of making such a mistake; and (5) the sign or symbolic value of the product. Consumer behavior is influenced by the interaction of facets in some situations where consumers are high on some facets and low on other facets of involvement (Kapferer \& Laurent, 1985). 
The CIP scale has been widely used in various studies (e.g., Trauer, 2006; Jin \& Sparks, 2017). The involvement construct has been studied extensively in the field of leisure and tourism (e.g., Bolfing, 1988; Filo et al., 2013; Gross \& Brown, 2008; Havitz \& Howard, 1995; Jamrozy, Backman, \& Backman, 1996; Warnick \& Bojanic, 2012). Research has shown that involvement can be used to explore tourist experiences (Gross \& Brown, 2008) and has a positive impact on interpreting satisfaction (Hwang, Lee, \& Chen, 2005). Hu and Yu (2007) suggest that involvement is an important construct to explain attitudes and behaviors in the context of recreational and touristic activities. Involvement is postulated as a tool for tourist segmentation (Havitz \& Dimanche, 1990). For example, tourists can be classified according to their involvement profiles with touristic activities, recreational products, and consumer goods (Dimanche et al.,1993). Other studies offered support for the effectiveness of involvement as a classification tool (e.g., Hu \& Yu, 2007; Fesenmaier \& Johnson, 1989). The Consumer Involvement Profiles (CIP) scale could differ from one product category to another due to the difference in perceived hedonic or sign values as well as in risk importance and probability (Kapferer \& Laurent, 1993). Different versions of CIP have been used in empirical marketing studies and for the Chinese consumers (e.g., O'Cass $\&$ Choy, 2008). The validity of the scale for the Chinese consumers in different product categories needs to be further tested.

\section{Personality}

Personality represents the collective action of an individual's major psychological subsystems (Mayer, 2007). Personality has been drawn upon extensively in the context of tourism to predict certain touristic phenomena since it was first applied to tourist behavior (Plog, 1974). Research has investigated how personality types predicted tourist behavior (Jackson, Smith, \& Inbakaran, 2007) and how it was used to segment travelers (Dolnicar \& Gountas, 2011). Cohen (1972)'s classification of tourists is based on the degree of novelty and strangeness which tourists are seeking during their travel. This is in line with the notion that open people are more likely to accept novelty and variety than closed people. 'Adventurers' (American Express News Release, 1989) are connected to someone's extroversion and openness while these groups of tourists like to meet new people and experience something different. In addition, 'Allocentrics' and 'Psychocentrics' (Plog, 1974) are also connected to these two factors of personality. This research focuses on the influence of extroversion on tourists' intended behavior.

Based on the literature review, this research aims to explore Chinese tourists' motivations and involvement in adventure activities. Furthermore, it investigates if and how personality and location affect Chinese tourists' motivation and involvement in adventure activities. By doing so, it adds to the current literature on adventure tourism of Chinese tourists and serves as a guide to market practitioners when designing market strategies to cater to the tastes of this group.

\section{Methodology}

\section{Sample and Data Collection}

Chinese tourists are the subject of this research. Data collection took place in two major tourist destinations and source markets in China, namely Chengdu and Xiamen. Chengdu, capital of southwest China's Sichuan province, received 210 million domestic and international tourists (Chengdu Statistical Bureau, 2018). Xiamen, a major city in Fujian province, received 78.3 million domestic and international tourists in 2017 (Xiamen Statistical Bureau, 2018). A convenience 
sampling approach was employed whereby potential respondents were approached during their leisure time in various recreational contexts (e.g., cafés) to ensure they had sufficient time to participate in the study. First, the research purpose was briefly explained before respondents were assured of data confidentially and non-disclosure to third parties, and their right to withdraw from the study at any time. A small incentive/gift was used to encourage participation.

\section{Instrument}

Following a review of the literature, a questionnaire was developed, refined through pretesting and employed to collect data. The questionnaire was comprised of five parts. First, respondents' preferred adventure activities were established by choosing three of seven prominent adventurous activities whereby images of these adventure activities - water rafting, hiking, hot air ballooning, snorkeling, rainforest walking, kayaking, and bungee jumping - were presented (ensuring that respondents' understanding of these activities is consistent). Subsequent questions asked about potential locations (either in China or overseas) where respondents would like to participate in the chosen activities and the reasons for choosing the locations. The next two sections ascertained respondents' involvement in and motivation for adventure activities, measured respectively by a 15-item involvement scale, developed by Laurent and Kapferer (1985), and a simplified version (containing 32-items) of the motivation measure scale developed by Beard and Ragheb (1983). Both scales have been successfully replicated by many studies and been found consistent over time. Next, respondents' openness and extroversion of their personality was ascertained, using a 10-item developed by Yoo and Gretzel (2011), adapted from the International Personality Item Pool (IPIP, 2008). A 7-point Likert-scale was utilized for all three scales (1 equaled strongly disagree, 7 equaled strongly agree). Finally, demographic information such as gender, age, education, occupation and place of residence was collected. A back-to-back translation method was utilized whereby the instrument was initially designed in English, then translated into Chinese, and translated back into English. This back-to-back translation was conducted by two independent native Chinese speakers, one of whom had a professional background in translation. The final instrument was administered in Chinese.

\section{Data Analyses}

A total of 325 questionnaires were distributed. Of those, 73 questionnaires were considered invalid due to the high number of missing responses and/or an inclination to choose the same response option - common problems reported by several studies examining cultural differences in responses to a Likert scale (Chen, Lee, \& Stevenson, 1995; Lee, Jones, Mineyama, \& Zhang, 2002). Consequently, 252 valid questionnaires were utilized for data analysis by SPSS version 22.0. Descriptive analysis, exploratory factor analysis (EFA), T-test, and ANOVA analysis were employed for data analysis. Descriptive analyses were conducted to indicate the adventure activities and locations that Chinese tourists may like (Questions 1, 2 \& 3). EFAs were performed to test the robustness of existing scales on a Chinese sample for adventure tourism (Question 4). T-tests were performed to test potential differences caused by gender, location and personality (Questions 2, 3, \& 5).

\section{Results}

\section{Respondent Profile}

The sample was equally divided in terms of gender. The majority of respondents $(57 \%)$ were aged between 26 and 40, followed by respondents in the 19-25-year age group (31\%). Almost 
$40 \%$ of the sample held a college diploma for professional training, while $38 \%$ had completed a university degree. The clear majority of the sample $(60 \%)$ was working for non-government departments or administrative organizations. Not surprisingly in view of the data collection sites, most respondents resided in Sichuan (52\%), followed by residents from Fujian (37\%).

\section{Adventure Activities - Preferences in General, by Gender and by Location}

Table 1 details the most popular adventure activities in general, by gender and by location. Hot air ballooning, snorkeling and white-water rafting were the most popular activities respondents would like to try for both genders. These activities appeared to be fun, novel and adventurous and require participants to challenge themselves either physically or mentally. While males and females showed almost equal interests in participating in the various adventure activities, a significant difference was apparent in terms of rainforest walking and bungee jumping. Hiking and rainforest walking are eco-friendly activities that allow participants to be widely exposed to nature. They require a sense of discovery and exploration apart from physical endurance. Females displayed greater interest in rainforest walking while males appeared to favor bungee jumping more. Males may wish to challenge themselves in extreme activities like bungee jumping to conquer their fear of gravity. Alternatively, females may look for an exotic experience offering excitement of the unknown and a chance to gain knowledge about nature.

Respondents had a slight preference in selecting overseas than domestic (China) for the various adventure activities, especially for snorkeling, bungee jumping, and hot air ballooning. Bungee jumping, snorkeling and kayaking are the three activities that respondents were least preferred to conduct a domestic location. This may be due to the ready availability of adventure activities, resources and safety concerns.

Respondents rated their reasons for their location choice (domestic vs overseas) for their preferred adventure activities (Table 2). An overseas location was chosen for safety and security, good service, good facilities and reliable insurance; whereas a domestic location was chosen mainly for convenience, reasonable price, safety and security, and good service. There was a significant statistical difference between the two groups (domestic vs overseas) on the ratings of all factors except recommendation (Table 2).

\section{Motivation for Adventure Activities}

Exploratory factor analysis (EFA) was conducted, using a principal component method with varimax rotation, to test the applicability and validity of the motivation scale in the Chinese context (Table 3). In accordance with the four sub-scales identified by Beard and Ragheb (1983), a fixed factor number was used as a decision rule to extract four factors. Items with loadings lower than. 50 were discarded. As per Table 3, the final 4-factor solution explained $60 \%$ of the total variance, with the four factors explaining $30 \%, 14 \%, 9 \%$, and $7 \%$ of the total variance respectively. The Kaiser-Meyer-Olkin Measure (KMO) of sampling adequacy was .868, indicating a satisfactory level for the appropriateness of the factor analysis. The chi-square value of Bartlett's test of sphericity was 3140.361 , significant at .000 level, indicative of the correlation among variables being sufficiently significant for factor analysis. Results of a reliability analysis indicated good reliabilities (Field, 2009), with Cronbach's alpha for the four factors being .890, .841, .858 and .851 respectively. 
Mean values for the four dimensions of motivation were 5.62, 5.40, 5.05, and 4.38 respectively. Stimulus-avoidance appeared to be the main motivation for the respondents to participate in adventure activities. The three most important motivations to participate in adventure activities were all from this construct, namely 1) relax mentally $(\mu=5.93), 2)$ relieve stress and tension $(\mu=5.85)$, and 3$)$ avoid the hustle and bustle of daily activities $(\mu=5.73)$. This was followed by intelligence (exploration). Conversely, social was the least motivator, as the three least important motivations were all from this construct, namely 1) be socially competent and skillful $(\mu=4.12), 2)$ gain a feeling of belonging $(\mu=4.24)$, and 3$)$ gain others' respect $(\mu=4.37)$. Thus, respondents were motivated for an opportunity to thrill and unwind, to escape from their daily living environment rather than for social reasons.

T-tests were employed to examine potential differences in motivations based on gender and the location for adventure activities (Tables $4 \& 5$ ). There was a significant difference between males and females on the intelligence dimension whereby females were more motivated than males $(\mathrm{t}=-.28, \mathrm{p}=0.034)$ to learn and explore something new in adventure activities. It could be that those female respondents were more sensitive to and keen for a sense of exploration, such as in rainforest walking, one of their preferred adventure activities. But, more studies are warranted to further explore gender differences in adventure tourism. No differences in terms of motivations for participating in adventure activities based on gender were observed for Stimulus-avoidance, Competence-Mastery, and Social reasons (Table 4).

Significant differences in motivation were observed for respondents wanting to participate in adventure activities overseas versus in China relating to Intelligence $(\mathrm{t}=-4.40, \mathrm{p}=.000)$, Stimulus-avoidance $(\mathrm{t}=-2.44, \mathrm{p}=.015)$, and Social $(\mathrm{t}=-2.09, \mathrm{p}=.038)$. Scores were higher for the former compared to the latter. There was no significant difference between the two groups in relation to the Competence-Mastery dimension. (Table 5). Clearly, an overseas location was considered better than a domestic location in meeting the motivations to explore, to thrill and unwind, and to facilitate socialization among like-minded people.

\section{Involvement in Adventure Activities}

Exploratory factor analysis (EFA) was conducted, using a principal component method with varimax rotation (Table 6). Previous research suggested that importance and pleasure could merge into one dimension when examining activities (Dimanche et al., 1993). In addition, the risk dimension was related to risk probability of choosing the wrong location and resultant negative consequences that can be treated as one dimension of involvement. Consequently, a fixed factor numbers extraction was utilized as a decision rule to extract three factors, namely importancepleasure, sign, and risks. The final 3 -factor solution explained $59 \%$ of the total variance, with the three factors accounting for $27 \%, 20 \%$, and $12 \%$ of the total variance respectively. The EFA indicates that the CIP scale is applicable in the research context.

Mean values of the three dimensions were 5.46, 4.9, and 4.11 respectively for ImportancePleasure, Sign and Risks, indicating that the respondents attached high values to the perceived adventure tourism experience, although they were moderately concerned of the risks associated with the choice of locations for the adventure activities. T-test was performed (Table 7) to further examine whether the perceived involvement levels might be influenced by location (overseas vs 
domestic). No differences were observed between respondents who chose domestic and overseas locations regarding the Importance-Pleasure and Risk dimensions of involvement. This is not surprising as the respondents were only moderately concerned of the location for adventure activities. However, there was a significant difference between those two groups in terms of Sign dimension of involvement in adventure activities $(t=-5.58, p=.011)$. It implies that conducting the adventure activities in an overseas location would result in a higher symbolic value associated with self-esteem and self-identity.

\section{Effect of Personality on Motivation and Involvement for Adventure Activities}

Only two dimensions of the IPIP scale (i.e., extroversion and openness) adapted from Yoo and Gretzel (2011) were included in the study and tested by Exploratory factor analysis (EFA) using a principal component method with varimax rotation (Table 8). Extracted factors explained $62 \%$ of the total variance, with the two factors accounting for $44 \%$ and $18 \%$ respectively. The measurements for the two scales remained the same as that Yoo and Gretzel (2011), a validation of the robustness of the scale in a Chinese sample.

To explore the influence of personality (introversion vs extroversion) on motivations and involvement, a median split of the sample was employed and t-tests were performed to compare these two groups in terms of their motivations and involvement in adventure activities (Tables 9 \& 10). T-tests showed that there was no difference between introverted and extroverted respondents in terms of Stimulus-avoidance, but there were significant differences between these two groups engaging in adventure activities for reasons such as Intelligence $(t=-2.98, p=0.003)$, Competence-Mastery $(\mathrm{t}=-4.93, \mathrm{p}=0.000)$ and Social $(\mathrm{t}=-4.27, \mathrm{p}=0.000)$. Regarding involvement, there was a significant difference in Importance-Pleasure dimension $(t=-4.75, p=0.000)$ and Sign dimension $(\mathrm{t}=-2.97, \mathrm{p}=0.003)$. There were no significant differences in Risk dimension between these two groups.

Results imply that introverted respondents were slightly less motivated for adventure activities due to social reasons or physical challenge. Conversely, extraversion may be more associated with motivations for exploration, socialization and self-enhancement in skills in adventure activities. It also implies that extraversion may increase the likelihood of attaching a higher symbiotic value and pleasure to adventure activities. The findings are consistent to previous studies (e.g., Yoo \& Gretzel, 2011) that travellers who are extraverts and open are more likely to be motivated by enjoyment/self-enhancement and are more likely to contribute to online communications and travel reviews. The finding of this study also indicates that risk concerns may not be influenced by personality (introversion vs extroversion).

\section{Discussion}

This research suggests that Chinese tourists may prefer overseas locations to participate in adventure activities. The majority of respondents who chose hot air ballooning, bungee jumping and snorkelling would like to conduct these activities overseas. Respondents who chose an overseas or domestic location for adventure activities were motivated differently for stimulusavoidance, intelligence, and social reasons. Participating in adventure activities overseas gives travellers a greater probability of getting away from their daily environment due to the long distance away from home. Participants expect to meet others overseas with the same interests in adventure activities. When they return home, they gain a sense of ego-enhancement or prestige by 
recounting their overseas adventure activity experience to all the people they know (Dann, 1977; Lundberg, 1972). Future research could explore how overseas adventure experiences boost tourists' intelligence or self-esteem/ego-enhancement on their own and compared with adventure experiences in their home country. This is particularly the case for female respondents.

The geographic convenience and cost efficiency could be drivers for China's domestic adventure tourism development. Participating in adventure activities in China might avoid possible risks associated with language barriers and unfamiliarity with the destination. Conversely, perceived reliable safety and security measures, facility maintenance, emergency evacuation, and quality services were key drivers for overseas adventure activity participation. Chinese domestic tour operators should devise initiatives to build trust and reputation by improving adventure coach/guide' knowledge and skills, logistical support, arrangements for emergency medical assistance and evacuation (Buckley, 2006). Outbound and overseas tour operators may consider providing special arrangements for Chinese tourists to minimize a sense of unfamiliarity and language barriers.

Results show that respondents differ in the Sign dimension in terms of location for adventure activities. Participating in adventure activities overseas expresses their self-identify to a greater extent. This finding is reflective of respondents' ego-involvement (Sherif \& Cantril, 1947) with adventure activities. It is possible that this ego involvement is due to respondents considering adventure activities to be important and meaningful to them. This may be due to the pleasure derived from their participation or the belief that their participation in adventure activities is a reflection of themselves. Because they are ego involved with adventure activities, they care more about the destination of adventure activities. In other words, where respondents participate in adventure activities reflects the type of person they are and their status in their social class.

Results confirm that Stimulus-avoidance and Intelligence are the two most important motivational forces for tourists to participate in adventure activities. This finding is in accordance with Mannell \&Iso-Ahola's (1987) theorization that approach (seeking) and avoidance (escape) are the two forces constituting the core parts of leisure motivation. Stimulus-avoidance is comparable to anomie suggested by Dann (1977) or escape/relaxation identified by Crompton (1979). Intelligence also corresponds to novelty and education identified as cultural motives by Crompton (1979). The escape dimension took on a greater weight than the seeking dimension.

However, respondents differ in terms of the seeking component when they have a chance to participate in adventure activities either in China or overseas. When respondents have an opportunity to participate in adventure activities outside China, they would like to seek or explore a new experience overseas. Competence-Mastery and Social are additional motivational forces to participate in adventure activities. This finding supports the social psychological model of tourist motivation proposed by Iso-Ahola (1980), where tourists wish to get away from their personal world (personal reward) involving troubles and difficulties (Stimulus-avoidance) and also their interpersonal world (interpersonal reward), including friends and relatives (Social). Meanwhile, tourists may also wish to gain personal rewards such as feelings of mastery (Competence-Mastery) and ego-enhancement as well as interpersonal rewards such as increased social interaction (Social). 
In general, findings are in line with the four subscales (Stimulus-avoidance, Competence-Mastery, Intelligence, Social) of the leisure motivation scale (Beard \& Ragheb, 1983).

Motivation to conduct adventure activities for the thrill or relaxation is unchanged by personality. However, extroverted respondents could be more motivated in adventure activities for discovery, for meeting new and different people, for gaining a feeling of belongingness, and for challenging their abilities. Extroverts are likely to be more involved in adventure activities for selfindulgence in pleasure and prestige enhancement. In contrast, introverts were less motivated by social purposes or for pleasure attainment.

\section{Conclusion}

This study demonstrates that the consumer involvement profile (Importance-Pleasure, Sign, and Risk) and the leisure motivation scale (Intelligence, Competence-Mastery, Social, and Stimulus-avoidance) are applicable to adventure activities in the context of Chinese tourists. Future research may explore the applicability of these two scales in the context of tourists from other nations. This gains the power of generalizability of the scales benefiting future research exploring adventure activities. The research also shed lights on how gender, location and personality affects consumers' motivation and participation in adventure tourism activities.

One limitation of this study is the relatively small sample size $(\mathrm{N}=252)$ and the sampling locations. The sample of this study was largely confined to people residing in Chengdu and Xiamen, two leading, second-tier cities in China. The sample size is good for testing the relationship between the constructs but may be insufficient to generalize the findings to all Chinese tourists in adventure activities. For future research, a larger sample drawn from more cities in China will produce results that are more generalizable. In addition, data may be collected in other countries in order to explore whether the involvement profile scale and the leisure motivation scale are applicable to people with different cultural backgrounds. Furthermore, this research did not cover all dimensions of personality such as neuroticism, agreeableness and conscientiousness. Each dimension may have an influence on tourist involvement and motivation to participate in adventure activities. Further research may explore the influence of the other three dimensions of personality on involvement and motivation of tourists when engaging in adventure activities.

\section{References}

American Express News Release. (1989). Unique Four Nation Travel Study Reveals Traveller Types. London: American Express.

Beard, J. G., \& Ragheb, M. G. (1983). Measuring leisure motivation. Journal of leisure research.

Bolfing, C. P. (1988). Integrating consumer involvement and product perceptions with market segmentation and positioning strategies. The Journal of Consumer Marketing, 5(2), 49-57.

Buckley, R. (2006). Adventure tourism. Cambridge, MA, USA; Wallingford, Oxon, UK: CABI Pub.

Buckley, R. C. (2007). Adventure tourism products: price, duration, size, skill, remoteness. Tourism Management, 28, 1428-1433.

Buckley, R. (2012). Rush as a key motivation in skilled adventure tourism: Resolving the risk recreation paradox. Tourism Management 33: 961-970. 
Buckley, R., McDonald, K., Duan, L., Sun, L., \& Chen, L. X. (2014). Chinese model for mass adventure tourism. Tourism Management, 44, 5-13.

Cater, C. I. (2006). Playing with risk? Participant perceptions of risk and management implications in adventure tourism. Tourism Management, 27(2), 317-325.

Chang, R. C. Y., Kivela, J., \& Mak, A. H. N. (2010). Food preferences of Chinese tourists. Annals of Tourism Research, 37(4), 989-1011.

Chen, C., Lee, S., \& Stevenson, H. W. (1995). Response Style and Cross-Cultural Comparisons of Rating Scales among East Asian and North American Students. Psychological Science, $6(3), 170-175$.

Chengdu Tourism Bureau. (2018). Overview of Tourism Development in 2017. Retrieved 02/12/2018, from http://www.cdta.gov.cn/show-65-29198-1.html

Choi, T., Liu, S., Pang, K., \& Chow, P. (2008). Shopping behaviors of individual tourists from the Chinese Mainland to Hong Kong. Tourism Management, 29(4), 811-820.

Chou, C.-j., \& Huang, C.-y. (2010). Involvement theory in constructing bloggers' intention to purchase travel products. Tourism Management, 31(4), 513-526.

Chow, I., \& Murphy, P. (2008). Travel activity preferences of chinese outbound tourists for overseas destinations. Journal of Hospitality and Leisure Marketing, 16(1-2), 61-80.

Cohen, E. (1972). Toward a Sociology of International Tourism. Social Research, 39(1), 164.

Crompton, J. L. (1979). Motivations for pleasure vacation. Annals of Tourism Research, 6(4), 408424.

Dann, G. M. S. (1977). Anomie, ego-enhancement and tourism. Annals of Tourism Research, 4(4), 184-194.

Dimanche, F., Havitz, M. E., \& Howard, D. R. (1993). Consumer Involvement Profiles as a Tourism Segmentation Tool. Journal of Travel \& Tourism Marketing, 1(4), 33-52.

Dolnicar, S., \& Gountas, J. (2011). Personality and motivation matter in touring holidays: a preliminary investigation into heterogeneity among touring travelers. Tourism analysis, 16(3), 329-342.

Fes, N, 2019, Domestic tourism continues to grow in China, Tourism Review news, retrived from https://www.tourism-review.com/chinese-domestic-tourism-keeps-growing-news10925.

Fesenmaier, D. R., \& Johnson, B. (1989). Involvement-based segmentation. Tourism Management, 10(4), 293-300.

Field, A. P. (2009). Discovering statistics using SPSS. London; Los Angeles: SAGE.

Filo, K., Chen, N., King, C., \& Funk, D. C. (2013). Sport tourists involvement with a destination: a stage-based examination. Journal of Hospitality \& Tourism Research, 37(1), 100-124.

Freedman, J. L. (1964). Involvement, discrepancy, and change. The Journal of Abnormal and Social Psychology, 69(3), 290-295.

Gross, M. J., \& Brown, G. (2008). An empirical structural model of tourists and places: progressing involvement and place attachment into tourism. Tourism Management, 29(6), 1141-1151.

Gyimóthy, S., \& Mykletun, R. J. (2004). Play in adventure tourism. Annals of Tourism Research, 31(4), 855-878.

Havitz, M. E., \& Dimanche, F. (1990). Propositions for testing the involvement construct in recreational and tourism contexts. Leisure Sciences, 12(2), 179-195.

Havitz, M. E., \& Howard, D. R. (1995). How Enduring Is Enduring Involvement? A Seasonal Examination of Three Recreational Activities. Journal of Consumer Psychology, 4(3), 255276. 
Hu, B., \& Yu, H. (2007). Segmentation by craft selection criteria and shopping involvement. Tourism Management, 28(4), 1079-1092.

Hwang, S., Lee, C., \& Chen, H. (2005). The relationship among tourists' involvement, place attachment and interpretation satisfaction in Taiwan's national parks. Tourism Management, 26(2), 143-156.

IPIP. (2008). International personality item pool: A scientific collaboratory for the development of advanced measures of personality traits and other individual differences. Retrieved 10/05, 2014, from http://ipip.ori.org/

Iso-Ahola, S. E. (1980). The social psychology of leisure and recreation. Dubuque, Iowa: W. C. Brown Co. Publishers.

Jackson, M. S., Smith, D., \& Inbakaran, R. (2007). Predicting Tourist Crime Victimization Using Tourism Personality Types, Sydney, N.S.W.

Jamal, S. A., Aminudin, N., \& Kausar, D. R. (2019). Family adventure tourism motives and decision-making: A case of whitewater rafting. Journal of Outdoor Recreation and Tourism, 25, 10-15.

Jamrozy, U., Backman, K. F., \& Backman, S. J. (1996). Involvement and opinion leadership in tourism. Annals of Tourism Research, 23(4), 908-924.

Jin, X., \& Wang, Y. (2016). Chinese Outbound Tourism Research: A Review. Journal of Travel Research, 55(4), 440-453.

Jin, X, \& Sparks, B. (2017). Barriers to offering special interest tour products to the Chinese outbound group market. Tourism Management, 59, 205-215.

Johnson, P., \& Thomas, B. (1992). Choice and demand in tourism: Mansell Publishing.

Kapferer, J. N., \& Laurent, G. (1985). Consumers Involvement Profiles: New Empirical Result. Advances in consumer research, 12(1).

Kapferer, J.-N., \& Laurent, G. (1993). Further evidence on the consumer involvement profile: Five antecedents of involvement. Psychology \& Marketing, 10(4), 347-355.

Krugman, H. E. (1965). The Impact of Television Advertising: Learning Without Involvement. The Public Opinion Quarterly, 29(3), 349-356.

Krugman, H. E. (1966). The Measurement of Advertising Involvement. The Public Opinion Quarterly, 30(4), 583-596.

Lee, J. W., Jones, P. S., Mineyama, Y., \& Zhang, X. E. (2002). Cultural differences in responses to a likert scale. Research in nursing \& health, 25(4), 295-306.

Lo, A., Qu, H., \& Wetprasit, P. (2013). Realms of Tourism Spa Experience: The Case of Mainland Chinese Tourists. Journal of China Tourism Research, 9(4), 429-451.

Lundberg, D. E. (1972). Why Tourists Travel. Cornell Hotel and Restaurant Administration Quarterly, 12(4), 64-70.

Mannell, R.C \& Iso-Ahola, S.E. (1987). Psychological nature of leisure and tourism experience. Annals of Tourism Research, 14 (3), 314-331.

Maslow, A. H. (1943). A theory of human motivation. Psychological review, 50(4), 370.

Mayer, J. D. (2007). Personality: a systems approach. Boston: Pearson/Allyn \& Bacon.

Mitchell, A. A. (1979). Involvement: A potentially important mediator of consumer behavior. Advances in consumer research, 6(1), 191-196.

Mittal, B. (1989). Measuring purchase-decision involvement. Psychology and Marketing, 6(2), 147-162.

Murray, C., \& Nakajima, I. (1999). The leisure motivation of Japanese managers: A research note on scale development. Leisure studies, 18(1), 57-65. 
O'Cass, A., \& Choy, E. (2008). Studying Chinese generation Y consumers' involvement in fashion clothing and perceived brand status. Journal of Product \& Brand Management, 17(5), 341352.

Page, S., \& Dowling, R. K. (2002). Ecotourism. New York: Prentice Hall.

Plog, S. C. (1974). Why Destination Areas Rise and Fall in Popularity. Cornell Hotel and Restaurant Administration Quarterly, 14(4), 55-58.

Poon, A. (1993). Tourism, technology and competitive strategies. Wallingford, England: C.A.B. International.

Prebensen, N. K., Woo, E., Chen, J. S., \& Uysal, M. (2013). Motivation and involvement as antecedents of the perceived value of the destination experience. Journal of travel research, $52(2), 253-264$.

Qiu, H. Z., Yuan, J. X., Ye, B. H., \& Hung, K. (2013). Wine tourism phenomena in China: an emerging market. International Journal of Contemporary Hospitality Management, 25(7), 1115-1134.

Ryan, C., \& Mo, X. (2002). Chinese visitors to New Zealand-Demographics and perceptions. Journal of Vacation Marketing, 8(1), 13-27.

Sherif, M., \& Cantril, H. (1947). The psychology of ego-involvements: social attitudes \& identifications. New York: John Wiley and Sons.

Sung, H. Y., Morrison, A. M., \& O'leary, J. T. (2000). Segmenting the adventure travel market by activities: From the North American industry providers' perspective. Journal of Travel \& Tourism Marketing, 9(4), 1-20.

Swarbrooke, J., Beard, C., Leckie, S., \& Pomfret, G. (2003). Adventure tourism: the new frontier. Oxford; Boston: Butterworth-Heinemann.

Trauer, B. (2006). Conceptualising special interest tourism - Frameworks for analysis. Tourism Management, 27, 183-200.

Traylor, M. B. (1981). Product involvement and brand commitment. Journal of Advertising Research, 21(6), 51-56.

Walle, A. H. (1997). Pursuing risk or insight - Marketing adventures. Annals of Tourism Research, 24(2), 265-282.

Wan, Y. K. P. (2013). Mainland Chinese gamblers' casino design preferences. Journal of Vacation Marketing, 19(4), 359-374.

Wang, P. (2011). Branding New Zealand to Chinese Tourists: Case Study of Shanghai World Expo, Adelaide, S.A.

Warnick, R. B., \& Bojanic, D. C. (2012). The Role of Purchase Decision Involvement in a Special Event. Journal of Travel Research, 51(3), 357-366.

Weber, K. (2001). Outdoor adventure tourism: A Review of Research Approaches. Annals of Tourism Research, 28(2), 360-377.

Wen, Z. (1997). China's domestic tourism: impetus, development and trends. Tourism Management, 18(8), 565-571.

Witt, C. A., \& Wright, P. L. (1992). Tourist motivation: life after Maslow. In P. Johnson \& B. Thomas (Eds.), Choice and demand in tourism. (pp. 33-55). London: Mansell Publishing

Wong, C. B., Wong, K. L. K., Ng, H. C., \& Wong, M. H. (2013). Mainland Chinese Tourists' Expectations, Perceived Performance of and Satisfaction towards Shopping Malls in Hong Kong. GSTF Business Review (GBR), 2(3), 134.

Wong, I. A. (2012). Casino travel motivations of Chinese tourists: differences in visitation attributes. Tourism review international, 16(3-4), 217-226. 
Wong, I. A., \& Rosenbaum, M. S. (2011). Beyond hardcore gambling: understanding why mainland Chinese visit casinos in Macau. Journal of Hospitality \& Tourism Research, $36(1), 32-51$.

UNWTO. (2018). Tourism Highlights, 2018 Ediction. Retrieved 25/04, 2018, from https://www.slovenia.info/uploads/dokumenti/unwto_tourism_highlights_2018.pdf

Xiamen Statistical Bureau. (2018). Overview of Tourism Development in 2017. Retrieved 25/10/2018, from http://www.stats-xm.gov.cn/2018/

Ye, B. H., Qiu, H. Z., \& Yuen, P. P. (2011). Motivations and experiences of Mainland Chinese medical tourists in Hong Kong. Tourism Management, 32(5), 1125-1127.

Yoo, K., \& Gretzel, U. (2011). Influence of personality on travel-related consumer-generated media creation. Computers in Human Behavior, 27(2), 609-621.

Zaichkowsky, J. L. (1985). Measuring the Involvement Construct. The Journal of Consumer Research, 12(3), 341-352. 
Table 1. Adventure Activity Preference by Gender and Location (N=252)

\begin{tabular}{|c|c|c|c|c|c|c|c|c|c|c|}
\hline & Overall & & Male & & Female & & Domestic & & Overseas & \\
\hline & Rank & No & Rank & No & Rank & No & Rank & No & Rank & No \\
\hline $\begin{array}{l}\text { Hot air } \\
\text { ballooning }\end{array}$ & 1 & 122 & 1 & 58 & 1 & 64 & 4 & 41 & 1 & 81 \\
\hline Snorkeling & 2 & 104 & 2 & 56 & 4 & 48 & 6 & 26 & 2 & 78 \\
\hline $\begin{array}{l}\text { White } \\
\text { water } \\
\text { rafting }\end{array}$ & 3 & 100 & 3 & 50 & 3 & 50 & 1 & 44 & 3 & 56 \\
\hline $\begin{array}{l}\text { Rainforest } \\
\text { walking }\end{array}$ & 4 & 97 & 7 & 38 & 2 & 59 & 3 & 42 & 4 & 55 \\
\hline Hiking & 5 & 90 & 5 & 44 & 5 & 46 & 2 & 43 & 5 & 47 \\
\hline Kayaking & 6 & 80 & 6 & 40 & 6 & 40 & 5 & 37 & 7 & 43 \\
\hline $\begin{array}{l}\text { Bungee } \\
\text { jumping }\end{array}$ & 7 & 66 & 4 & 45 & 7 & 21 & 7 & 19 & 5 & 47 \\
\hline
\end{tabular}


Table 2. Perceptions of Key Requirements of Adventure Activity Destinations - Overall and by Location

\begin{tabular}{|l|l|l|l|l|l|l|l|l|l|}
\hline & All $^{\mathbf{a}}$ & $\begin{array}{l}\text { Std. } \\
\text { Dev }\end{array}$ & $\begin{array}{l}\text { Mean } \\
\text { Domestic }\end{array}$ & Rank & $\begin{array}{l}\text { Mean } \\
\text { Overseas }\end{array}$ & Rank & $\begin{array}{l}\text { Mean } \\
\text { difference }\end{array}$ & t-value & Sig. \\
\hline Convenience & 5.39 & 1.539 & 5.76 & 1 & 5.11 & 6 & .642 & 3.428 & $.001^{*}$ \\
\hline Reasonable Price & 5.24 & 1.519 & 5.64 & 2 & 4.95 & 7 & .695 & 3.525 & $.001^{*}$ \\
\hline Safety and Security & 5.83 & 1.277 & 5.42 & 3 & 6.13 & 1 & -.709 & -4.331 & $.000^{*}$ \\
\hline Good Service & 5.69 & 1.277 & 5.33 & 4 & 5.96 & 2 & -.636 & -3.851 & $.000^{*}$ \\
\hline Good Facilities & 5.64 & 1.257 & 5.23 & 5 & 5.93 & 3 & -.698 & -4.326 & $.000^{*}$ \\
\hline Reliable Insurance & 5.52 & 1.543 & 5.08 & 6 & 5.85 & 4 & -.768 & -3.849 & $.000^{*}$ \\
\hline Recommendation & 4.83 & 1.646 & 4.65 & 7 & 4.95 & 7 & -.302 & -1.380 & .169 \\
\hline Tour Guide & 4.99 & 1.730 & 4.54 & 8 & 5.32 & 5 & -.782 & -3.480 & $.001^{*}$ \\
\hline
\end{tabular}

* significant difference at $\alpha \leq 0.05 ;{ }^{\mathrm{a}} \mathrm{n}=231,{ }^{\mathrm{b}} \mathrm{n}=98,{ }^{\mathrm{c}} \mathrm{n}=133$ 
Table 3. EFA results of Motivation Items

\begin{tabular}{|c|c|c|c|c|c|}
\hline Factor/Item & Mean & Loading & Eigen-value & $\begin{array}{c}\text { Variance } \\
\text { Explained }\end{array}$ & $\begin{array}{c}\text { Reliability } \\
\text { Alpha }\end{array}$ \\
\hline Factor 1: $\quad$ Intelligence & 5.4 & & 7.936 & 30.522 & .890 \\
\hline Intell:to learn about things around me & 5.17 & .726 & & & \\
\hline Intel2:to satisfy my curiosity & 5.55 & .692 & & & \\
\hline Intel3:to explore new ideas & 5.37 & .810 & & & \\
\hline Intel4:to learn about myself & 5.51 & .759 & & & \\
\hline Intel5to expand my knowledge & 5.47 & .812 & & & \\
\hline Intel6:to discover new things & 5.61 & .741 & & & \\
\hline Intel7:to be creative & 5.18 & .607 & & & \\
\hline Intel8:to use my imagination & 5.27 & .564 & & & \\
\hline Factor 2: $\quad$ Social & 4.38 & & 3.596 & 13.831 & .841 \\
\hline Social3:to develop close friendships & 4.70 & .592 & & & \\
\hline Social5:to reveal my thoughts, feelings, or physical skills to others & 4.57 & .746 & & & \\
\hline Social6:to be socially competent and skillful & 4.12 & .838 & & & \\
\hline Social7:to gain a feeling of belonging & 4.24 & .770 & & & \\
\hline Social8:to gain other's respect & 4.37 & .707 & & & \\
\hline Factor 3: Competence-Mastery & 5.05 & & & 8.809 & .858 \\
\hline Compmast3:to improve my skill and ability in doing them & 5.13 & .681 & 2.290 & & \\
\hline Compmast4: to be active & 5.26 & .721 & & & \\
\hline Compmast5: to develop physical skills and abilities & 5.19 & .770 & & & \\
\hline Compmast6: to keep in shape physically & 4.62 & .594 & & & \\
\hline Compmast7: to use my physical abilities & 4.82 & .711 & & & \\
\hline Compmast8: to develop physical fitness & 5.27 & .765 & & & \\
\hline Factor 4: Stimulus- avoidance & 5.62 & & 1.778 & 6.839 & .851 \\
\hline Stimavoid1: to slow down & 5.34 & .568 & & & \\
\hline Stimavoid3:to relax physically & 5.43 & .675 & & & \\
\hline Stimavoid4:to relax mentally & 5.93 & .794 & & & \\
\hline Stimavoid5:to avoid the hustle and bustle of daily activities & 5.73 & .752 & & & \\
\hline Stimavoid6:to rest & 5.48 & .729 & & & \\
\hline Stimavoid7:to relieve stress and tension & 5.85 & .760 & & & \\
\hline Stimavoid8:to unstructure my time & 5.49 & .748 & & & \\
\hline Total & & & & 60.000 & 0.906 \\
\hline
\end{tabular}

Extraction Method: Principal Component Analysis. $\mathrm{N}=214, \mathrm{KMO}=.868$, Bartlett's Test of Sphericity: Approx, Chi-Square $=3140.361, \mathrm{df}=325$, sig. $=.000$,

Total variance explained $=60.000$, Rotation Method: Varimax with Kaiser Normalisation. Rotation converged in 5 iterations 
Table 4. Difference in Motivations based on Gender

\begin{tabular}{|c|c|c|c|c|c|c|c|c|}
\hline \multicolumn{3}{|c|}{ Male $^{\text {a }}$} & \multicolumn{2}{|c|}{ Female $^{b}$} & \multirow[b]{2}{*}{$\begin{array}{c}\text { Mean } \\
\text { difference }\end{array}$} & \multirow{2}{*}{\multicolumn{2}{|c|}{$\begin{array}{cc}\mathrm{t}- & \mathrm{s} \\
\text { value } & \end{array}$}} & \multirow[b]{2}{*}{ ignificance } \\
\hline & Mean & Rank & Mean & Rank & & & & \\
\hline $\begin{array}{l}\text { Stimulus- } \\
\text { avoidance }\end{array}$ & 5.56 & 1 & 5.67 & 1 & -.11054 & \multicolumn{2}{|c|}{-.810} & .419 \\
\hline Intelligence & 5.26 & 2 & 5.54 & 2 & -.28140 & \multicolumn{2}{|c|}{-.659} & $.034 *$ \\
\hline $\begin{array}{l}\text { Competence- } \\
\text { Mastery }\end{array}$ & 5.08 & 3 & 5.02 & 3 & -.05595 & \multicolumn{2}{|c|}{-.379} & .705 \\
\hline Social & 4.43 & 4 & 4.32 & 4 & -.10937 & \multicolumn{2}{|c|}{-.660} & .510 \\
\hline \multicolumn{9}{|c|}{${ }^{*}$ significant difference at $\alpha \leq 0.05 ;{ }^{\mathrm{a}} \mathrm{n}=122 ;{ }^{\mathrm{b}}=120$} \\
\hline & \multicolumn{2}{|c|}{ Domestic } & \multicolumn{2}{|c|}{ Overseas } & \multirow{2}{*}{\multicolumn{2}{|c|}{$\begin{array}{c}\text { Mean } \\
\text { difference }\end{array}$}} & \multirow[b]{2}{*}{$\begin{array}{c}\mathrm{t}- \\
\text { value }\end{array}$} & \multirow[b]{2}{*}{ Sig. } \\
\hline & Mean & Rank & Mean & Rank & & & & \\
\hline $\begin{array}{l}\text { Stimulus- } \\
\text { avoidance }\end{array}$ & 5.42 & 1 & 5.76 & 1 & \multicolumn{2}{|c|}{-.33304} & $\begin{array}{c}- \\
2.439\end{array}$ & $.015^{*}$ \\
\hline Intelligence & 5.08 & 2 & 5.65 & 2 & \multicolumn{2}{|c|}{-.56897} & $\begin{array}{c}- \\
4.397\end{array}$ & $.000^{*}$ \\
\hline $\begin{array}{l}\text { Competence- } \\
\text { Mastery }\end{array}$ & 4.92 & 3 & 5.15 & 3 & \multicolumn{2}{|c|}{-.22605} & $\begin{array}{c}- \\
1.521\end{array}$ & .130 \\
\hline Social & 4.18 & 4 & 4.52 & 4 & \multicolumn{2}{|c|}{-.34840} & $\begin{array}{c}- \\
2.091 \\
\end{array}$ & $.038^{*}$ \\
\hline
\end{tabular}

* significant difference at $\alpha \leq 0.05 ;{ }^{\mathrm{a}} \mathrm{n}=98 ;{ }^{\mathrm{b}} \mathrm{n}=133$ 
Table 6. EFA results of Adventure Activity Involvement

\begin{tabular}{|c|c|c|c|c|c|}
\hline Factor/Item & Mean & Loading & Eigen-value & $\begin{array}{l}\text { Variance Explained } \\
(\%)\end{array}$ & Reliability Alpha \\
\hline Factor 1: Importance-Pleasure & 5.46 & & 3.467 & 26.667 & .776 \\
\hline $\operatorname{Im} 1:$ I attach great importance to this activity & 4.63 & .634 & & & \\
\hline $\operatorname{Im} 3$ :I can say that this activity interests me a lot & 5.55 & .843 & & & \\
\hline P12:this activity is like giving a gift to yourself & 5.24 & .545 & & & \\
\hline P12:I get pleasure from this activity & 5.92 & .812 & & & \\
\hline $\mathrm{P} 13$ :for me, this activity is somewhat a pleasure & 5.93 & .745 & & & \\
\hline Factor 2: Sign & 4.9 & & 2.655 & 20.422 & .846 \\
\hline $\begin{array}{l}\text { Sign1: you can tell about a person by whether or not } \\
\text { they participate this activity }\end{array}$ & 5.05 & .839 & & & \\
\hline $\begin{array}{l}\text { Sign2: where you participate this activity gives a } \\
\text { glimpse of the type of person you are }\end{array}$ & 4.85 & .888 & & & \\
\hline $\begin{array}{l}\text { Sign3: where you participate this activity tells } \\
\text { something about you }\end{array}$ & 4.80 & .826 & & & \\
\hline Factor 3: Risks & 4.11 & & 1.586 & 12.198 & .739 \\
\hline $\begin{array}{l}\text { Conseq1: it is annoying if you participate this activity } \\
\text { somewhere unsuitable }\end{array}$ & 4.32 & .715 & & & \\
\hline $\begin{array}{l}\text { Conseq } 3 \text { : if your choice of the location of doing this } \\
\text { activity prove to be poor, you would be upset }\end{array}$ & 4.09 & .640 & & & \\
\hline $\begin{array}{l}\text { Prob1: it is rather complicated to choose where to } \\
\text { undertake this activity }\end{array}$ & 4.12 & .736 & & & \\
\hline $\begin{array}{l}\text { Prob2: where to undertake this activity, you never } \\
\text { really know whether it is the right choice }\end{array}$ & 4.20 & .688 & & & \\
\hline $\begin{array}{l}\text { Prob3: when faced with choosing the location for } \\
\text { undertaking this activity, you always feel at a loss to } \\
\text { make the right choice }\end{array}$ & 3.83 & .724 & & & \\
\hline Total & & & & 59.287 & .728 \\
\hline
\end{tabular}


Table 7. Differences in Involvement based on Location

\begin{tabular}{|c|c|c|c|c|c|c|c|}
\hline & \multicolumn{2}{|c|}{ Domestic } & \multicolumn{2}{|c|}{ Overseas } & \multirow[b]{2}{*}{$\begin{array}{c}\text { Mean } \\
\text { difference }\end{array}$} & \multirow[b]{2}{*}{ t-value } & \multirow[b]{2}{*}{ Sig. } \\
\hline & Mean & Rank & Mean & Rank & & & \\
\hline Importance-pleasure & 5.34 & 1 & 5.56 & 1 & -.22057 & -1.866 & .063 \\
\hline Sign & 4.65 & 2 & 5.08 & 2 & -.42517 & -2.579 & $.011 *$ \\
\hline risk & 4.17 & 3 & 4.07 & 3 & -.10135 & .666 & .503 \\
\hline
\end{tabular}

* significant difference at $\alpha \leq 0.05 ;{ }^{a} \mathrm{n}=98 ;{ }^{\mathrm{b}} \mathrm{n}=133$

\section{Table 8. EFA results of Openness and Extroversion Dimensions of Personality}

\begin{tabular}{|c|c|c|c|c|c|c|}
\hline Factor/Item & Mean & & Loading & Eigen-value & $\begin{array}{l}\text { Variance } \\
\text { explained }\end{array}$ & Reliability \\
\hline Openness dimension & & & & 4.427 & 44.267 & 0.853 \\
\hline I enjoy hearing new ideas & 4.33 & 1.536 & .837 & & & \\
\hline I enjoy thinking about things & 4.15 & 1.503 & .783 & & & \\
\hline I get excited by new ideas & 4.84 & 1.320 & .713 & & & \\
\hline I have a vivid imagination & 4.00 & 1.658 & .692 & & & \\
\hline Extroversion dimension & & & & 1.780 & 17.798 & 0.826 \\
\hline I start conversions & 5.16 & 1.401 & .858 & & & \\
\hline I feel comfortable around people & 5.29 & 1.303 & .771 & & & \\
\hline I don't mind being the centre of attention & 5.70 & 1.134 & .709 & & & \\
\hline I talk a lot to different people at parties & 5.45 & 1.342 & .702 & & & \\
\hline I make friends easily & 5.24 & 1.324 & .694 & & & \\
\hline Total & & & & & 62.065 & 0.858 \\
\hline
\end{tabular}

Extraction Method: Principal Component Analysis. $\mathrm{N}=242, \mathrm{KMO}=.848$, Bartlett's Test of Sphericity: Approx, Chi- Square $=1053.986, \mathrm{df}=45$, sig. $=.000$,

Total variance explained $=62.065$, Rotation Method: Varimax with Kaiser Normalisation. Rotation converged in 3 iterations. 
Table 9. Differences in Motivation based on Personality

\begin{tabular}{|c|c|c|c|c|c|c|c|c|}
\hline & \multicolumn{3}{|c|}{ Introverted $^{\mathrm{a}}$} & \multicolumn{2}{|c|}{ Extroverted $^{b}$} & \multirow[b]{2}{*}{$\begin{array}{c}\text { Mean } \\
\text { differenc } \\
\mathrm{e} \\
\end{array}$} & \multirow[b]{2}{*}{ t-value } & \multirow[b]{2}{*}{ significance } \\
\hline & $\begin{array}{l}\text { Grand } \\
\text { Mean }\end{array}$ & Mean & Rank & Mean & Rank & & & \\
\hline Stimulus-avoidance & 5.62 & 5.51 & 1 & 5.72 & 1 & -.20626 & -1.461 & .145 \\
\hline Intelligence & 5.40 & 5.15 & 2 & 5.55 & 2 & -.40611 & -2.972 & $.003 *$ \\
\hline Competence-Mastery & 5.05 & 4.65 & 3 & 5.37 & 3 & -.71410 & -4.916 & $.000 *$ \\
\hline Social & 4.38 & 3.98 & 4 & 4.69 & 4 & -.70419 & -4.266 & $.000 *$ \\
\hline
\end{tabular}

*significant difference at $\alpha \leq 0.05 ;{ }^{a} \mathrm{n}=100 ;{ }^{\mathrm{b}} \mathrm{n}=131$

Table 10. Differences in Involvement based on Personality

\begin{tabular}{|c|c|c|c|c|c|c|c|}
\hline & \multicolumn{2}{|c|}{ Introverted $^{\mathrm{a}}$} & \multicolumn{2}{|c|}{ Extroverted ${ }^{b}$} & \multirow[b]{2}{*}{$\begin{array}{c}\text { Mean } \\
\text { difference }\end{array}$} & \multirow[b]{2}{*}{$\mathrm{t}$-value } & \multirow[b]{2}{*}{ significance } \\
\hline & Mean & Rank & Mean & Rank & & & \\
\hline Importance-pleasure & 5.16 & 1 & 5.71 & 1 & -.557 & -4.754 & $.000 *$ \\
\hline Sign & 4.62 & 2 & 5.12 & 2 & -.502 & -2.969 & $.003 *$ \\
\hline Risk & 4.70 & 3 & 4.90 & 3 & -.195 & -1.235 & .218 \\
\hline
\end{tabular}

*significant difference at $\alpha \leq 0.05 ;{ }^{a} \mathrm{n}=100 ;{ }^{\mathrm{b}} \mathrm{n}=131$ 